KONSTAN
JURNAL FISIKA DAN PENDIDIKAN FISIKA
Volume 3, Nomor 2, Desember 2018
$\begin{array}{r}\text { E-ISSN : 2460-9129 dan P-ISSN : 2460-9110 } \\ \text { http://jurnalkonstan.ac.id/index.php/jurnal }\end{array}$

\title{
PEMANFAATAN MULTIMEDIA PEMBELAJARAN INTERAKTIF PADA MATA KULIAH PEMBELAJARAN IPA POKOK BAHASAN ENERGI DAN USAHA DI PROGRAM STUDI PGMI STAI MUHAMMADIYAH BLORA
}

\author{
Eko Bayu Gumilar ${ }^{*}$, Kristina Gita Permatasari ${ }^{2}$ \\ ${ }^{1}$ Program Studi Pendidikan Guru Madrasah Ibtida'iyah (PGMI) \\ STAI Muhammadiyah Blora
}

\section{Info Artikel}

Sejarah Artikel:

Diterima November 2018

Disetujui Desember 2018

Dipublikasikan Desember

2018

Kata Kunci:

Multimedia,

Pembelajaran

Ipa,Interaktif, Energi

dan Usaha

\begin{abstract}
Abstrak
Energi dan Usaha merupakan salah satu Sub Materi dalam Perkuliahan Pembelajaran IPA Program studi PGMI di STAI Muhammadiyah Blora. Materi bahasan tersebut menjelaskan bentuk-bentuk energi, perubahan energi, energi mekanik, usaha serta hubungan energi dan usaha. Berdasarkan hasil observasi dibebarapa SMP, SMA dan perguruan tinggi banyak kendala yang dialami Guru dan Dosen dalam menyampaikan materi Pembelajaran IPA khususnya energi dan usaha. Hal tersebut disebabkan karena kurangnya media pembelajaran yang berkualitas. Tujuan penelitian ini adalah memanfaatkan media pembelajaran IPA pokok bahasan energi dan usaha yang berkualitas sebagai alat bantu Dosen dan Guru dalam menyampaikan materi pembelajaran.

Media pembelajaran merupakan perangkat lunak yang lebih sesuai dimasukkan ke perangkat pembelajaran karena digunakan untuk proses belajar mengajar. Sehingga pengukuran kualitas media pembelajaran dikatakan baik jika memenuhi aspek-aspek kualitas antara lain: (1) Validitas, (2) Kepraktisan, dan (3) Keefektifan.

Hasil pengujian menunjukkan bahwa program multimedia pembelajaraninteraktif yang dibuat ini berkualiatas karena memenuhi kriteria valid, praktis, dan efektif. Berdasarkan hasil tersebut dapat disimpulkan bahwa program yang dikembangkan layak dijadikan sebagi media pembelajaran dan dapat dimanfaatkan dalam Perkuliahan pembelajaran Ipa pokok bahasan energi dan usaha untuk Program studi PGMI
\end{abstract}

(C) 2018 Universitas Islam Negeri Mataram

\footnotetext{
* Corresponding Author: ekobayugumilar@gmail.com
}

Alamat korespodensi:

Gedung Pasca Sarjana Lantai 3 Kampus 2 UIN Mataram, Jl. Gajah Mada 100 Jempong Mataram, Indonesia Email: jurnalkonstan@uinmataram.ac.id 


\section{PENDAHULUAN}

Perkembangan teknologi komputer telah mencapai kemajuan yang sangat mengagumkan.Hampir semua bidang pekerjaan didunia telah dikendalikan oleh komputer. Sama seperti bidang yang lain, komputer juga sangat erat kaitannya dengan dunia pendidikan. Munculnya produk elektronik canggih yang dapat digunakan dalam bidang pendidikan telah memberikan peluang kepada para pendidik untuk meningkatkan kualitas pendidikan melalui peningkatan proses belajar mengajar [1]. Implementasi kurikulum 2013 yang diberlakukan mulai tahun 2013 sangat menuntun para guru dan Dosen untuk bersifat kreatif dalam menyusun silabus yang sesuai dengan kondisi dan situasi siswa. Selain itu guru dituntut juga lebih kreatif dalam membuat media pembelajaran agar dapat menjelaskan teori dan konsep yang abstrak menjadi tervisualisasi sehingga mudah dipahami dan dimengerti serta menarik bagi siswa dan mahasiswa.

Media pembelajaran dapat dibuat berbasis teknologi informasi dengan membuat animasi-animasi yang menarik yang dapat memvisualisasikan teori dan konsep IPA yang abstrak. Hal ini dapat dibuat sendiri oleh guru dan dosen yang menguasai program presentasi seperti PowerPoint dan Flash atau guru dan dosen juga dapat memperoleh dengan cara surfing di internet untuk memperoleh bahanbahan tersebut. Disadari bahwa teknologi komputer belum merata di Indonesia sehingga banyak daerah yang belum terjangkau oleh teknologi tersebut. Namun di kota-kota besar teknologi informasi sudah banyak digunakan didalam proses pembelajaran. Hal ini menuntut para guru IPA di kota besar untuk menguasai teknologi sehingga dapat digunakan untuk mendukung proses belajar mengajar yang mereka selenggarakan.

Mata pelajaran yang sering dikeluhkan oleh Mahsiswa adalah Pembelajaran IPA hal tersebut disebabkan oleh beberapa faktor, antara lain kurangnya sarana belajar, alat peraga IPA dan metode belajar. Selain itu, mata KuliahPembelajaran IPA juga menghabiskan waktu yang lebih banyak dalam proses belajar mengajar khususnya materi energi dan usaha [2]. Dalam observasi yang peneliti lakukan di Beberapa Sekolah SMP, SMA dan Program Studi PGMI di STAI Muhammadiyah Blora, pembelajaran IPA pokok bahasan energi dan usaha bagi kebanyakan siswa dan mahasiswa masih dirasakan sebagai bagian yang sulit dari IPA. Hal ini dikarenakan kurang tertariknya siswa pada materi tersebut. Adapun faktor penyebabnya, antara lain kurangnya sarana belajar, alat peraga dan media pembelajaran yang baik terlebih lagi di kota kecil seperti Blora. Energi dan Usaha merupakan salah satu pokok bahasan dari Pembelajaran IPA yang diberikan di Program Studi PGMI STAI Muhammadiyah Semester Gasal yang metode pembelajarannya dimulai dari hal yang bersifat kongkret ke hal yang bersifat abstrak. Maka dari itu, untuk memahami konsep-konsep dari energi dan usaha diwujudkan dengan contoh-contoh yang berkaitan dengan kehidupan sehari-hari dari mahasiswa. Dari hasil pengamatan pembelajaran energi dan usaha juga masih banyak menggunakan metode ceramah yang menjadikan mahasiswa bosan dalam mempelajari dan kurang optimal dalam memahaminya. Dalam konteks inilah, dapat dibuat media pembelajaran dengan memanfaatkan komputer sebagai media pembelajaran. 
Komputer merupakan salah satu alat elektronik yang komplek dan mempunyai banyak kelebihan. Komputer dapat digunakan sebagai alat Bantu guru dalam pembelajaran karena komputer mempunyai kemampuan untuk menerima dan memproses data. Pembelajaran berbasis komputer meningkatkan pemahaman konsep teoritik dengan kaedah simulasi,dan bantuan komputer dapat meningkatkan tahap pemahaman pelajaran dengan mudah. Bentuk pembelajaran dengan bantuan komputer seperti Computer Assisted Instructional atau disingkat CAI dapat menjadi pelengkap pengajaran kelas yang sedang berlansung.Dalam hal ini siswa memperoleh informasi dan keterampilan serta bantuan lansung dari komputer. Namun kendala yang muncul adalah kemampuan pendidik yang belum memadai sehingga pemanfaatan komputer dalam pembelajaran IPA kurang optimal, khususnya pembuatan media pengajaran.Simulasi dan animasi dapat dimanfaaatkan sebagai pendekatan abstraksi IPA sehingga terlihat nyata dan dapat dinikmati keindahannya. Bila semua pendidik mempunyai kreatifitas dalam menyampaikan ilmu IPA atau setidaknya mampu membuat simulasi sebagai media pengajaran dipastikan kesulitan yang dihadapi mahasiswa dalam pemahaman IPAakan terkurangi, dan masa depan pendidikan Indonesia akan semakin baik.Atas dasar latar belakang tersebut perlu dilakukan studi pembuatan suatu media pembelajaran tentang energi dan usaha yang lengkap dengan memberikan isi bahan ajar tentang energi dan usaha, latihan beserta pembahasan dan evaluasinya dengan software yang dikemas dalam bentuk compact disc (CD) yang berfungsi membantu proses pembelajaran yang sesuai dengan tujuan kompotensi yang telah ditentukan. Media pembelajaran dibuat dengan software macromediaflash.

\section{METODE PENELITIAN}

Penelitian ini termasuk penelitian dan pengembangan media pembelajaran berbasis multimedia. Penelitian pengembangan dapat diartikan sebagai suatu penelitian yang mengkondisikan suatu hal yang ada menjadi lebih baik dari segi kualitas, kapasitas, fungsi, manfaat dan lain-lain. Pengembangan berarti pula menjadikan yang semula abstrak menjadi konkret. Produk yang dihasilkan dalam penelitan ini berupa media pembelajaran interaktif IPA pada pokok bahasan energi dan usaha.

Penelitian ini telah dilaksanakan pada perkuliahan Pembelajaran IPA di Program Studi PGMI dan Subjek penelitian ini adalah media pembelajaran interaktif untuk mata KuliahIPA pokok bahasan energi dan usaha yang dirancang untuk bisa menampilkan gambar, suara, teks, animasi, dan simulasi.

\section{1) Desain Penelitian}

Dalam penyusunan desain media pembelajaran perlu memegang prinsip dasar yang dikenal dengan istilah desain instruksional (instructional design) yaitu suatu proses yang sistematis untuk menghasilkan materi pembelajaran yang efektif, detail, dan terinci, termasuk didalamnya proses dan bentuk evaluasinya yang harus dilaksanakan [3]. Adapun desain dalam penelitian ini mengacu pada pengembangan menurut Thiagarajan dkk dalam Yamasari [4], yaitu :

1. Tahap Define (pendefinisian) 
Tujuan dari tahap pendefinisian adalah untuk menetapkan dan mendefinisikan kebutuhan-kebutuhan di dalam pembuatan media pembelajaran. Tahapan ini terdiri dari berbagai kegiatan yaitu :

a. Analisis kebutuhan

b. Analisis kurikulum K-2013 materi energi dan usaha

c. Analisis aspek untuk mengembangkan bahan ajar IPA berbasis multimediayang bersifat mudah dan sederhana dalam pengembangannya.

d. Analisis tampilan media pembelajaran menggunakan multimedia interaktif yang diperoleh dari kajian pustaka.

2. Tahap Design (desain)

Tujuan pada tahap ini adalah untuk mendapatkan suatu bentuk perangkat media pembelajaran sesuai yang diinginkan.Tahap perancangan adalah:

a. Membuat format atau pola yang dibutuhkan dalam penyusunan materi di media pembelajaran.

b. Menyiapkan materi-materi yang berhubungan dengan konsep-konsep dasar energi dan usaha.

c. Membuat animasi dan simulasi yang berhubungan dengan konsepkonsep energi dan usaha.

d. Menyiapkan soal-soal yang berhubungan dengan energi dan usahauntuk bahan evaluasi.

e. Menyiapkan Perangkat keras yaitu komputer, dan perangkat lunak yaitu Macromedia Flash 8.

f. Perancangan Menu Sistem

g. Perancangan tampilan media pembelajaran

1) Rancangan tampilan awal

2) Rancangan tampilan kata pengantar

3) Rancangan tampilan menu utama

4) Rancangan tampilan standar kompetensi

5) Rancangan tampilan materi (tutorial)

6) Rancangan tampilan simulasi Keterangan

7) Rancangan tampilan evaluasi

8) Rancangan tampilan profil (penulis)

3. Tahap Development (Pengembangan/Pembuatan)

Pada tahapan ini media pembelajaran mulai dikembangkan sesuai apa yang sudah ditetapkan sebelumnya di dalam tahapan desain. Pada tahap ini peneliti membuat dan mengembangkan media pembelajaran dengan menggunakan software macromedia flash8.

4. Tahap Dessiminate (penyebaran)

Pada tahap penyebarluasan (disseminate) adalah mengujicobakan perangkat penelitian ke subyek yang lebih luas. Akan tetapi karena keterbatasan waktu dalam penelitian ini agar penelitian lebih efektif dan efisianmaka, pengukuran kualitas media pembelajaran energi dan usaha 
berbasismultimedia ini hanya mengacu terhadap pengukuran kualitas perangkat pembelajaran. Kualitas media pembelajaran dapat mengacu pada kriteria kualitas [4]. Suatu material dikatakan baik jika memenuhi aspekaspek kualitas, antara lain: (1). Validitas (Validity), (2). Kepraktisan (Practicaly), dan (3). Keefektifan (Effectiveness). Media pembelajaran berbasis multimedia pada pokok bahasan energi dan usaha dibuat berdasarkan indikator yang telah ditentukan dan disesuaikan dengan materi energi dan usaha. Pengembangan media pembelajaran berbasis multimedia dalam pembelajaran IPA pada materi energi dan usaha dikatakan berkualitas jika memenuhi indikator:

\section{a. Validitas ahli}

Validitas ini dimaksudkan untuk mengantisipasi kesalahan pada pengguna (peserta didik).Ahli materi memberikan penilaian terhadap aspek pembelajaran dan isi materi, sedangkan ahli media memberikan penilaian terhadap aspek tampilan dan aspek pemrograman.Data hasil validasi ahli materi dan ahli media dijadikan pertimbangan untuk melakukan revisi produk multimedia pembelajaran.Para ahli adalah validator yang berkompeten untuk menilai kualitas media pembelajaran dan memberi masukan atau saran untuk menyempurnakan media pembelajaran yang telah dibuat. Kepraktisan

Media pembelajaran visualisasi konsep IPA berbasis multimedia dikatakan praktis jika memenuhi indikator yaitu validator menyatakan bahwa media pembelajaran menggunakan tersebut dapat digunakan dengan sedikit atau tanpa revisi yang ditunjukkan dari hasil analisis lembar validasi.

\section{b. Keefektifan}

Media pembelajaran dikatakan efektif jika memenuhi indikator adanya respon positif dari pengguna dalam hal ini Dosen Pembelajaran IPA dan Guru Mata Pelajaran IPA yang ditunjukkan melalui angket yang diberikan.

\section{2) Teknik Pengumpulan Data}

Untuk memperoleh data yang dibutuhkan dalam pengembangan media pembelajaran, dimulai dengan dua tahap pengumpulan data yaitu tahap pertama sebelum pembuatan media pembelajaran dan tahap kedua setelah pembuatan media pembelajaran sebagai evaluasi produk yang dihasilkan:

\section{Wawancara}

Wawancara dilakukan dengan tanya jawab kepada pihak yang berkaitan dengan objek penelitian, dalam hal ini peneliti melakukan wawancara dengan Mahasiswa PGMI STAI Muhammadiyah Blora dan Dosen Pembelajaran IPA untuk mendapatkan masukan data tentang cara pengajaran IPA Serta beberapa sekolah tingkat SMP dan SMA sebagai bahan masukan untuk peningkatan produk. Data yang diperoleh adalah 
hambatan dalam proses belajar mengajar, kesulitan Mahasiswa dalam belajar IPA, beberapa materi IPA yang dirasa sulit dipahami mahasiswa, dan bagian apa dari materi yang harus dianimasikan agar lebih mudah dipahami oleh mahasiswa.

\section{Angket}

Berisi sejumlah pertanyaan tertulis yang digunakan untuk memperoleh tanggapan dalam pengujian program. Angket diberikan kepada ahli media, ahli materi IPA dan pengguna Dosen pembelajaran IPA serta Guru IPA untuk mendapatkan informasi mengenai respon terhadap media pembelajaran yang dibuat apakah layak atau tidak untuk digunakan dalam proses pembelajaran. Secara lengkap lembar angket tersebut terlampir pada lampiran.

\section{3) Instrumen Penelitian}

Instrumen penelitian adalah alat atau fasilitas yang digunakan oleh peneliti dalam mengumpulkan data agar pekerjaanya lebih mudah dan hasilnya lebih baik, dalam arti lebih cermat, lengkap, dan sistematis sehingga lebih mudah diolah [5]. Dalam penelitian ini instrument yang digunakan adalah :

1. Angket ahli media

2. Angket ahli materi (IPA)

3. Angket pengguna (guru)

Penggunaan lembar observasi untuk memudahkan dalam mendapatkan informasi awal untuk penyusunan media pembelajaran. Penggunaan kuesioner adalah cara pengumpulan data dengan menggunakan daftar pertanyaan (angket) atau daftar isian terhadap objek yang diteliti. Dengan kuesioner ini kita dapat mengetahui tentang keadaan/data diri, pengalaman, pengetahuan sikap atau pendapatnya tentang responden [5].

Model angket digunakan untuk mengukur indikator program yang berkenaan dengan isi program, tampilan program, kualitas teknis pemprograman, isi dan konsep materiIPA dari media pembelajaran yang dibuat.Angket menggunakan format respon empat poin dari skala Likert, dimana alternatif responnya adalah Sangat Setuju (SS), Setuju (S), Kurang Setuju (KS), Tidak Setuju (TS).Penentuan skor skala Likert dilakukan secara apriori. Bagi skala yang berarah positif akan mempunyai kemungkinankemungkinan skor 4 bagi Sangat Setuju (SS), skor 3 bagi Setuju (S), skor 2 bagi Kurang Setuju (KS), skor 1 bagi Tidak Setuju (TS). Sedangkan bagi skala yang berarah negatif maka kemungkinan skor itu menjadi sebaliknya.

Validitas yang digunakan dalam penelitian ini adalah validitas logis (logical validity).Untuk membuat validitas logis dalam penelitian ini, maka pembuatan instrumen mengikuti langkah-langkah yang benar dan hati-hati, yaitu dengan memecah variabel menjadi beberapa indikator, kemudian merumuskan butir-butir pertanyaan dan pernyataan. Dengan demikian, secara logis akan dicapai validitas instrumen seperti yang dikehendaki dalam penelitian ini. 


\section{4) Analisis Data}

1. Analisis kevalidan media pembelajaran interaktif

Penilaian dua validator untuk ahli materi yang terdiri dari dua orang dosen STAI Muhammadiyah Blora dan dua validator untuk ahli media yaitu dua orang dosen Multimedia STAI Muhammadiyah Blora terhadap kevalidan media pembelajaran interaktif meliputi aspek-aspek yaitu format, isi, bahasa, kesederhanaan, keterpaduan, penekanan, keseimbangan, bentuk, dan warna. Kegiatan yang dilakukan untuk menganalisis data ini adalah :

a. Membuat dan menganilisis tabel tersebut.

b. Mencari rata-rata tiap kriteria dari kedua validator dengan rumus:

$$
K_{i}=\frac{\sum_{h=1}^{3} V_{h i}}{3}
$$

Keterangan :

$K_{i}=$ Rata-rata kriteria ke- i

$V_{h i}=$ Skor hasil penilaian validator ke- $\mathrm{h}$ untuk kriteria ke- $\mathrm{i}$

$i=$ Kriteria

$h=$ Validator

Hasil yang diperoleh dimasukkan di kolom rata-rata pada lembar validasi media pembelajaran interaktif.[4]

c. Mencari rata-rata ketiga aspek dengan rumus:

$$
A_{i}=\frac{\sum_{i=1}^{n} K_{i j}}{n}
$$

Keterangan :

$A_{i}=$ Rata-rata aspek ke- $\mathrm{i}$

$K_{i j}=$ Skor hasil penilaian validator ke- $\mathrm{h}$ untuk criteria ke- i

$i=$ Aspek

$j=$ Kriteria

$i j=$ Aspek ke- $\mathrm{i}$ kriteria ke- $\mathrm{j}$

Hasil yang diperoleh dimasukkan di kolom rata-rata pada lembar validasi media pembelajaran interaktif.[4]

d. Mencari rata-rata total validasi ketiga aspek dengan rumus:

$$
R T V_{T K}=\frac{\sum_{i=1}^{3} A_{1}}{3}
$$


Keterangan :

$R T V_{T K}=$ Rata-rata totalvaliditas lembar kerja

$A_{i}=$ Rata-rata aspek ke- i

$i=$ Aspek

Hasil yang diperoleh dimasukkan di kolom rata-rata pada lembar validasi media pembelajaran interaktif.[4]

e. Mencocokkan rata-rata total dengan kriteria kevalidan:

$3 \leq R T V_{T K} \leq 4$ : valid

$2 \leq R T V_{T K} \leq 3$ : cukup valid

$1 \leq R T V_{T K} \leq 2 \quad$ : tidak valid

Hasil analisis ini sudah dapat digunakan untuk menentukan kevalidan karena keempat validator tersebut memang orang yang berkompeten dalam bidang multimedia pembelajaran dan materi Pembelajaran IPA. Revisi terhadap media pembelajaran interaktif dilakukan sehingga diperoleh media pembelajaran yang valid. [4]

2. Analisis kepraktisan media pembelajaran interaktif

Media pembelajaran visualisasi konsep Pembelajaran IPA berbasis multimedia dikatakan praktis jika memenuhi indikator yaitu validator menyatakan bahwa media pembelajaran menggunakan tersebut dapat digunakan dengan sedikit atau tanpa revisi yang ditunjukkan dari hasil analisis lembar validasi.

3. Analisis keefektifan media pembelajaran interaktif

Media pembelajaran dikatakan efektif jika memenuhi indikator adanya respon positif dari pengguna dalam hal ini Dosen Pembelajaran IPA yang ditunjukkan melalui angket yang diberikan.

a. Menghitung persentase guru yang memberikan tanggapan sesuai dengan kriteria tertentu, yaitu dengan rumus:

$R S=\frac{f}{n} x 100 \%$

$R S=$ Persentase guru dengan kriteria tertentu

$f=$ Banyaknya guru yang menjawab setuju

$n=$ Jumlah seluruh guru. [4]

b. Menentukan rata-rata respon positif guru, kemudian menentukan kategori respon atau tanggapan yang diberikan guru terhadap suatu kriteria dengan cara mencocokkan hasil persentase dengan kriteria positif .[4] yaitu:

$\begin{array}{ll}85 \% \leq R S & \text { : Sangat Positif } \\ 70 \% \leq R S<85 \% & \text { : Positif } \\ 50 \% \leq R S<70 \% & \text { : Kurang Positif }\end{array}$




$$
\begin{aligned}
& R S<50 \% \quad: \text { Tidak Positif } \\
& R S=\text { Respon guru terhadap kriteria tertentu }
\end{aligned}
$$

\section{Validitas produk}

Untuk menghasilkan produk yang berkualitas dan siap diuji cobakan perlu adanya uji validitas produk. Agar didapatkan hasil yang baik maka dalam validitas produk digunakan angket, dimana ahli media dan ahli teori tinggal mengisi angket sesuai dengan pertanyaan yang telah disediakan. Validitas produk untuk ahli media dan ahli materi dilakukan melalui konsultasi dan meminta penilaian kepada para ahli yang memiliki keahlian dalam bidangnya. Validitas produk meliputi aspek format, isi atau materi, bahasa, kesederhanaan, keterpaduan, penekanan, keseimbangan, bentuk, dan warna.

\section{Uji Coba Produk}

Uji coba produk dilakukan untuk mendapatkan data yang akan digunakan untuk melakukan revisi produk media pembelajaran IPA pada materi energi dan usaha. Uji coba dilakukan kepada pengguna mengenai kualitas media pembelajaran yang sedang dikembangkan.

Dalam uji coba produk pengembangan media pembelajaran interaktif ini, penulis menggunakan 2 orang DosenPembelajaran IPA, 1 Orang Guru SMP dan 1 orang Guru SMA . Data dari hasil uji coba ini akan dijadikan sebagai dasar dalam merevisi produk, sehingga produk yang dihasilkan benar-benar layak untuk digunakan dalam pembelajaran.

\section{HASIL DAN PEMBAHASAN}

\section{Hasil Pembuatan Program}

Setelah dilaksanakan tahap-tahap rancangan dalam pembuatan media yang telah ditetapkan maka dihasilkan media pembelajaran sesuai dengan rancangan sistem media pembelajaran Ipa energi dan usaha, agar tampilan terlihat menarik ditambahkan gambar, suara, animasi dan simulasiyang disesuaikan dengan materi. Dalam penelitian ini program media pembelajaran IPA pokok bahasan energi usaha ini dibuat menggunakan Software Macromedia Flash 8.

\section{Tampilan awal program}

Tampilan awal merupakan tampilan yang petama kali muncul ketika program dijalankan.Terdapat tombol masuk untuk melanjutkan ke tampilan berikutnya (Home). 


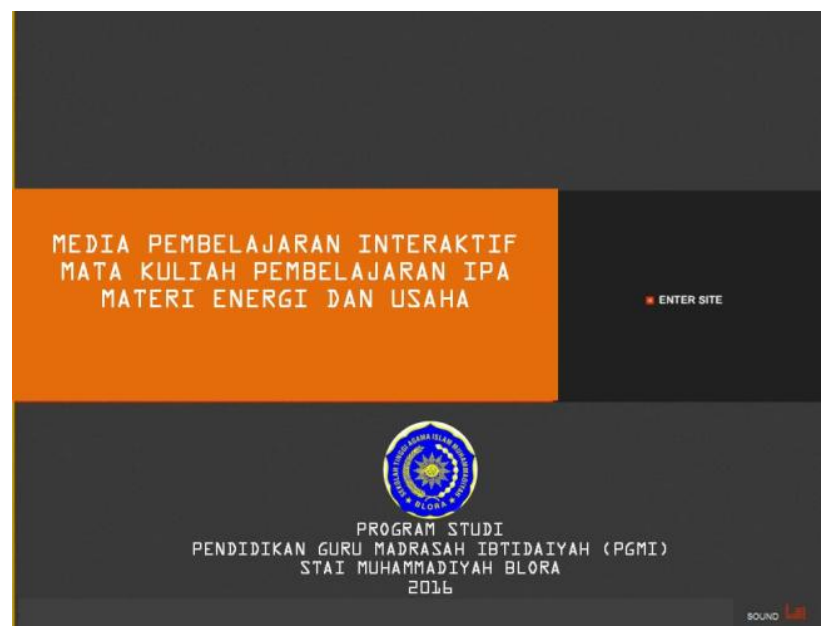

Gambar 1. Tampilan awal program

\section{Tampilan halaman depan (Home)}

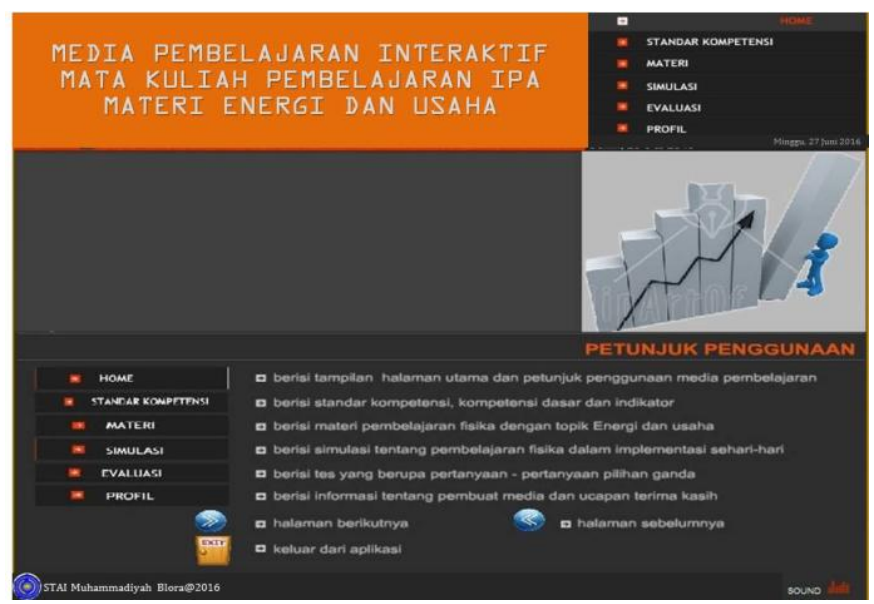

Gambar 2. Tampilan halaman depan

Tampilan home merupakan tampilan yang berisi uraian tentang tujuan dan petunjuk penggunaan media pembelajaran IPA pokok bahasan energi dan usaha. Di dalam tampilan home ini juga terdapat baris menu untuk masuk kehalaman selanjutnya yang bisa dipilih dengan mengklik salah satu tombolmenu yang ada, kemudian akan muncul tampilan menu pilihan yang diinginkan oleh pengguna. Tampilan menu utama ini memuat standar kompetensi, materi, simulasi, evaluasi, dan profil penulis, serta terdapat tombol kembali untuk menuju tampilan awal, dan terdapat tombol lanjut untuk melanjutkan ke tampilan menu utama. 


\section{Tampilan Standar Kompetensi}

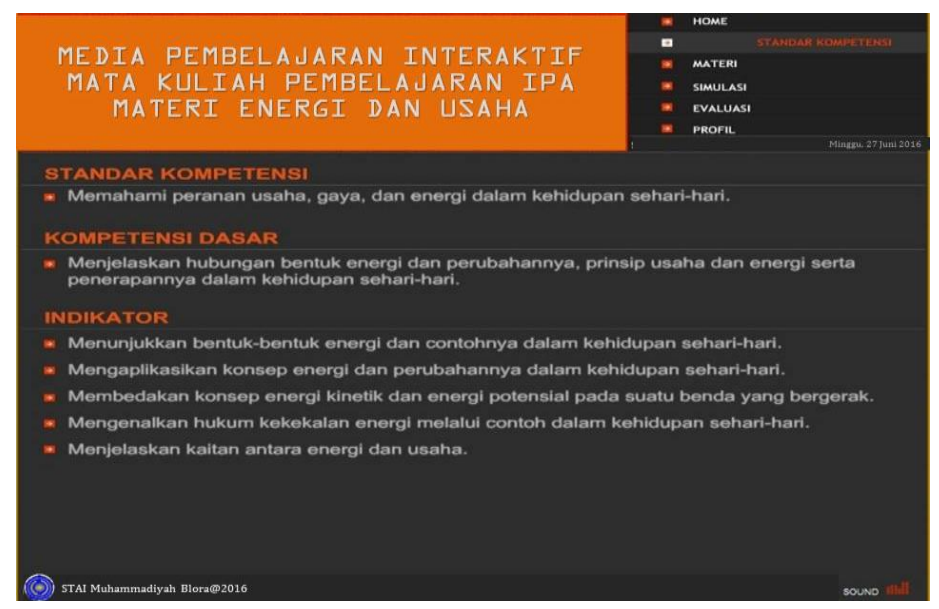

Gambar 3.Tampilan Standar Kompetensi

Menu standar kompetensi berisi standar kompetensi, kompetensi dasar dan indikator pencapaian yang merupakan tujuan dari pembelajaran ini.Tampilan terlihat seperti pada gambar diatas.

\section{Tampilan Materi}

Pada tampilan materi berisikan materi-materi yang menjadi pokok bahasan dalam media pembelajaran ini, yaitu.

a. Energi

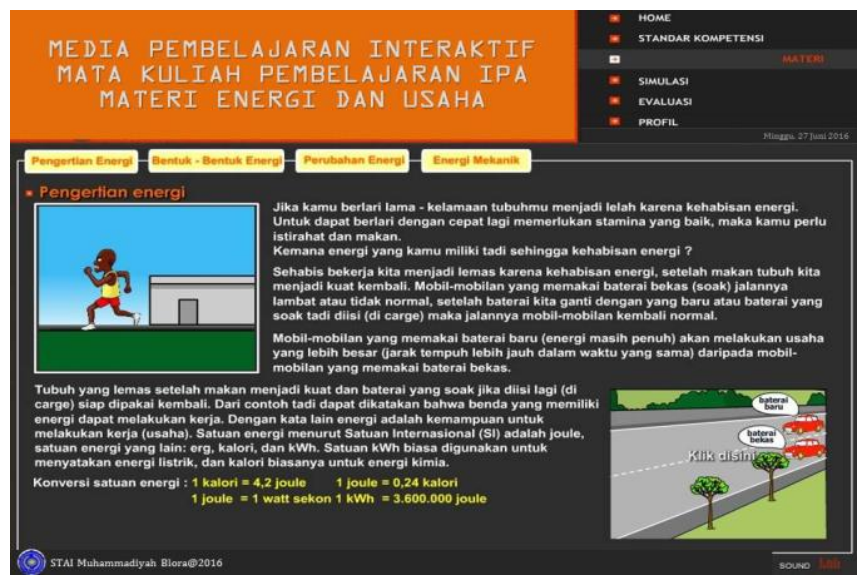

Gambar 4.Tampilan materi pengertian energi

Salah satu bagian tampilan materi (tutorial) yang telah dihasilkan seperti ditampilkan pada gambar di atas yang 
menjelaskan tentang pengertian energi.

b. Usaha

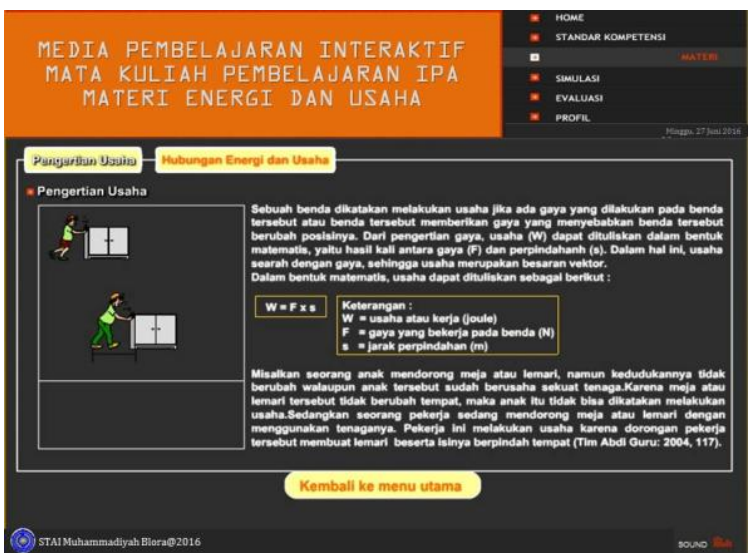

Gambar 5.Tampilan materi pengertian usaha

Salah satu bagian tampilan materi (tutorial) yang telah dihasilkan seperti ditampilkan pada gambar di atas yang menjelaskan tentangpengertian usaha.

\section{Tampilan Simulasi}

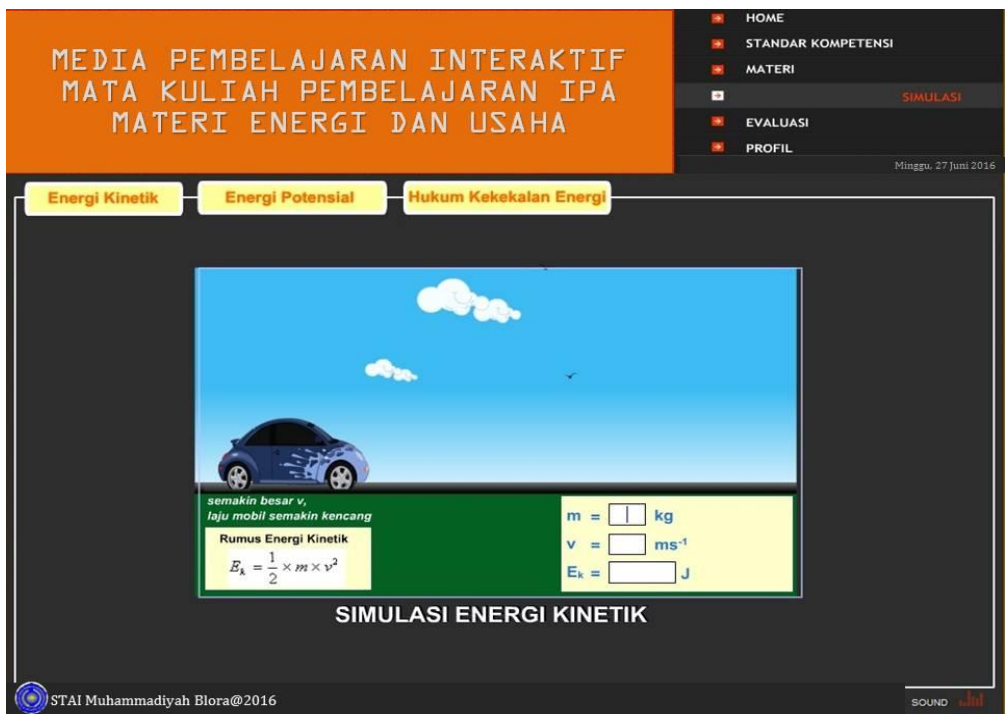

Gambar 6. Tampilan simulasi

Gambar di atas menampilkan simulasi yang disesuaikan dengan standar kompetensi yang dimuat, seperti simulasi tentang Energi Potensial, Energi Kinetik, Hukum Kekekalan Energi, dan Usaha. 


\section{Tampilan Evaluasi}

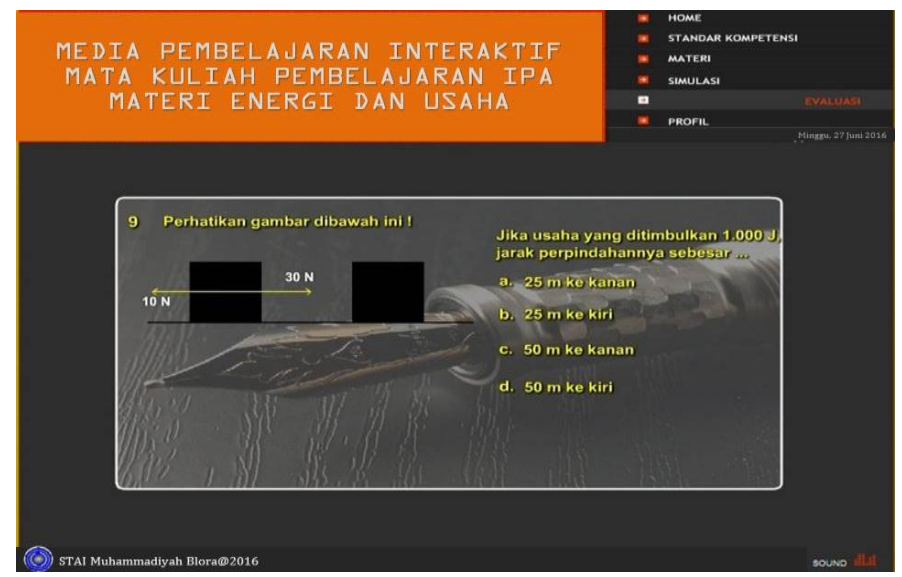

Gambar 7. Tampilan evaluasi

Tampilan evaluasi ini dimaksudkan untuk mengetahui sejauh mana pengguna memahami materi yang telah dipelajari.Pada tampilan latihan soal dinyatakan dalam bentuk pilihan ganda. Sebelum memulai latihan pengguna memasukkan namalalu ditampilkan soal-soal latihan secara acak. Untuk menjawab soal yang disajikan yaitu dengan menekan salah satu jawaban pilihan yang dianggap benar. Setelah mengerjakan soal-soal latihan sampai selesai akan muncul skor yang dicapai.

\section{Tampilan profil Penulis}

Menu ini berisi tentang identitas pembuat (Nama, email dan foto), hasil rancangan dapat dilihat pada gambar dibawah ini:

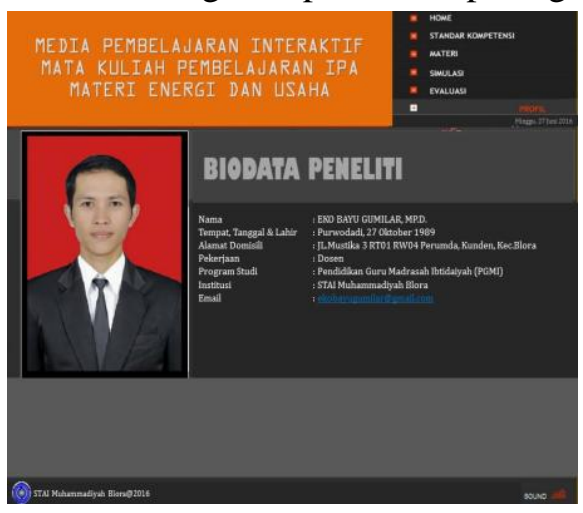

Gambar 8. Tampilan profil penulis

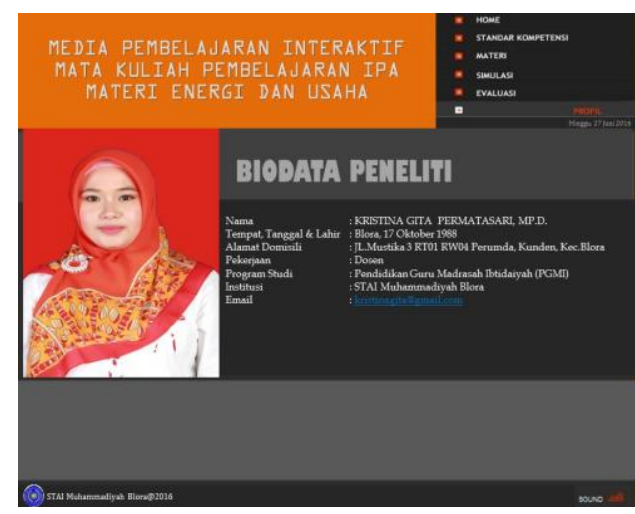

Gambar 9. Tampilan profil penulis

\section{A. Pengujian program}

Setelah program selesai dirancang, selanjutnya dilakukan proses pengujian terhadap program. Pengujian program dilakukan dengan menggunakan angket uji kevalidan ahli media, ahli materi dan respon dari pengguna. 
Analisis pengujian program ini bertujuan untuk mengetahui kualitas dan kelayakan media sebagai media pembelajaran IPA pokok bahasan energi dan usaha untuk Mahasiswa PGMI STAI Muhammadyah Blora. Pengujian media pembelajaran ini dilakukan dengan tigacara yaitu angket kepada ahli materi (IPA dan Fisika), angket ahli media, dan angket pengguna.

\section{Analisis kevalidan media pembelajaran energi dan usaha}

Kevalidan media pembelajaran energi dan usaha ini terdiri dari uji ahli materi dan uji ahli media.

Tabel 1. Daftar Validator Ahli Materi IPA

\begin{tabular}{ccc}
\hline No. & \multicolumn{1}{c}{ Nama } & Profesi \\
\hline 1. & A.Teguh Purnawanto M. Pd & Dosen STAI Muhammadiyah Blora \\
\hline 2. & Rina Murtiarini, M.Pd & Dosen STAI Muhammadiyah Blora \\
\hline
\end{tabular}

Tabel 2. Data Validasi Media Pembelajaran oleh Ahli Materi

\begin{tabular}{|c|c|c|c|c|c|}
\hline \multirow[t]{2}{*}{ Aspek } & \multirow[t]{2}{*}{ Kriteria } & \multicolumn{2}{|c|}{$\begin{array}{c}\begin{array}{c}\text { Validator } \\
\text { ke- }\end{array} \\
\end{array}$} & \multirow[t]{2}{*}{$\mathbf{K}_{\mathbf{i}}$} & \multirow[t]{2}{*}{$\mathbf{A}_{\mathbf{i}}$} \\
\hline & & 1 & 2 & & \\
\hline \multirow[t]{6}{*}{ Format } & 1. Kejelasan petunjuk penggunaan & 3 & 4 & 3,50 & \multirow[t]{6}{*}{3,08} \\
\hline & $\begin{array}{l}\text { 2. Kesesuaian format sebagai } \\
\text { lembar kerja }\end{array}$ & 3 & 3 & 3,00 & \\
\hline & $\begin{array}{l}\text { 3. Kesesuaian isian pada lembar } \\
\text { kerja dengan konsep atau } \\
\text { definisi yang diinginkan }\end{array}$ & 3 & 3 & 3,00 & \\
\hline & $\begin{array}{l}\text { 4. Keserasian warna, tulisan, dan } \\
\text { gambar pada media } \\
\text { pembelajaran interaktif }\end{array}$ & 4 & 3 & 3,50 & \\
\hline & $\begin{array}{l}\text { 5. Kesesuaian warna, tampilan } \\
\text { gambar dan tulisan pada materi } \\
\text { energi dan usaha }\end{array}$ & 3 & 3 & 3,00 & \\
\hline & $\begin{array}{l}\text { 6. Kesesuaian tampilan gambar } \\
\text { dan tulisan pada latihan soal }\end{array}$ & 2 & 3 & 2,50 & \\
\hline \multirow[t]{3}{*}{ Isi } & $\begin{array}{l}\text { 1. Kesesuaian tujuan } \\
\text { pembelajaran dengan } \\
\text { kurikulum }\end{array}$ & 4 & 4 & 4,00 & \multirow[t]{3}{*}{3,28} \\
\hline & 2. Kejelasan petunjuk belajar & 3 & 4 & 3,50 & \\
\hline & $\begin{array}{l}\text { 3. Kesesuaian antara materi energi } \\
\text { dan usaha pada media } \\
\text { pembelajaran interaktif }\end{array}$ & 3 & 4 & 3,50 & \\
\hline
\end{tabular}




\begin{tabular}{|c|c|c|c|c|c|}
\hline & 4. Kedalaman materi & 3 & 3 & 3,00 & \\
\hline & $\begin{array}{l}\text { 5. Kejelasan konsep energi dan } \\
\text { usaha yang disampaikan pada } \\
\text { media pembelajaran interaktif }\end{array}$ & 3 & 3 & 3,00 & \\
\hline & $\begin{array}{l}\text { 6. Kesesuaian animasi dalam } \\
\text { media pembelajaran interaktif } \\
\text { dengan konsep IPA yang } \\
\text { terdapat pada materi energi dan } \\
\text { usaha }\end{array}$ & 3 & 3 & 3,00 & \\
\hline & $\begin{array}{l}\text { 7. Kejelasan animasi dalam } \\
\text { menyampaikan konsep IPA } \\
\text { dalam media pembelajaran } \\
\text { interaktif }\end{array}$ & 3 & 3 & 3,00 & \\
\hline \multirow[t]{6}{*}{ Bahasa } & $\begin{array}{l}\text { 1. Kebakuan bahasa yang } \\
\text { digunakan }\end{array}$ & 3 & 3 & 3,00 & \multirow[t]{5}{*}{3,20} \\
\hline & $\begin{array}{l}\text { 2. Kemudahan dalam memahami } \\
\text { bahasa yang digunakan }\end{array}$ & 3 & 3 & 3,00 & \\
\hline & $\begin{array}{l}\text { 3. Keefektifan kalimat yang } \\
\text { digunakan }\end{array}$ & 3 & 4 & 3,50 & \\
\hline & $\begin{array}{l}\text { 4. Kelengkapan kalimat/informasi } \\
\text { yang dibutuhkan siswa }\end{array}$ & 3 & 3 & 3,00 & \\
\hline & $\begin{array}{l}\text { 5. Penggunaan kata sesuai dengan } \\
\text { Ejaan Yang Disempurnakan } \\
\text { (EYD) }\end{array}$ & 3 & 4 & 3,50 & \\
\hline & \multicolumn{4}{|l|}{$\mathrm{V}_{\text {ômedia }}$} & 3,18 \\
\hline
\end{tabular}

Keterangan:

$\mathrm{K}_{\mathrm{i}} \quad$ = Rata-rata tiap kriteria

$\mathrm{A}_{\mathrm{i}}=$ Rata-rata tiap aspek

$\mathrm{V}_{\text {omedia }}=$ Rata-rata total validasi

Hasil analisis ahli media ini sudah menunjukkan bahwa media pembelajaran energi dan usaha ini valid karena nilainya diatas 3 yang berarti kriterianya valid.

Tabel 3. Daftar Validator Ahli Media

\begin{tabular}{ccc}
\hline No. & Nama & Profesi \\
\hline 1. & M. Anwar, M.Pd & Dosen Multimedia \\
& & STAI Muhammadiyah Blora \\
\hline 2. & A. Irchamni, M.Pd & Dosen STAI Muhammadiyah Blora \\
\hline
\end{tabular}

Tabel 4. Data Validasi Media Pembelajaran oleh Ahli Media

\section{Aspek}

Kriteria
Validator $\mathbf{K}_{i}$

ke- 


\begin{tabular}{|c|c|c|c|c|c|}
\hline & & 1 & 2 & & \\
\hline \multirow[t]{4}{*}{ Kesederhanaan } & $\begin{array}{l}\text { 1. Animasi dalam media } \\
\text { pembelajaran interaktif } \\
\text { sederhana }\end{array}$ & 3 & 3 & 3,00 & 3,12 \\
\hline & $\begin{array}{l}\text { 2. Animasi dalam media } \\
\text { pembelajaran interaktif } \\
\text { mudah dimengerti }\end{array}$ & 2 & 4 & 3,00 & \\
\hline & $\begin{array}{l}\text { 3. Animasi yang disajikan } \\
\text { dalam media pembelajaran } \\
\text { sesuai dengan karakteristik } \\
\text { Untuk mempermudah } \\
\text { pemahaman }\end{array}$ & 3 & 3 & 3,00 & \\
\hline & $\begin{array}{l}\text { 4. Kalimat yang digunakan } \\
\text { mudah dimengerti }\end{array}$ & 4 & 3 & 3,50 & \\
\hline \multirow[t]{2}{*}{ Keterpaduan } & $\begin{array}{l}\text { 1. Urutan antar halaman sudah } \\
\text { sesuai }\end{array}$ & 3 & 4 & 3,50 & 3,50 \\
\hline & $\begin{array}{l}\text { 2. Petunjuk yang digunakan } \\
\text { dalam media pembelajaran } \\
\text { interaktif sudah sesuai }\end{array}$ & 3 & 4 & 3,50 & \\
\hline Penekanan & $\begin{array}{l}\text { 1. Animasi yang digunakan } \\
\text { pada setiap halaman ada } \\
\text { penekanan }\end{array}$ & 2 & 3 & 2,50 & 2,50 \\
\hline \multirow[t]{4}{*}{ Keseimbangan } & $\begin{array}{l}\text { 1. Ukuran animasi setiap } \\
\text { halaman sesuai }\end{array}$ & 3 & 3 & 3,00 & 2,75 \\
\hline & $\begin{array}{l}\text { 2. Ukuran tulisan setiap } \\
\text { halaman sesuai }\end{array}$ & 2 & 3 & 2,50 & \\
\hline & $\begin{array}{l}\text { 3. Ukuran gambar setiap } \\
\text { halaman sesuai }\end{array}$ & 3 & 3 & 3,00 & \\
\hline & $\begin{array}{l}\text { 4. Tata letak tulisan tiap } \\
\text { halaman seimbang }\end{array}$ & 2 & 3 & 2,50 & \\
\hline \multirow[t]{3}{*}{ Bentuk } & $\begin{array}{l}\text { 1. Animasi yang digunakan } \\
\text { menarik }\end{array}$ & 3 & 3 & 3,00 & 3,16 \\
\hline & $\begin{array}{l}\text { 2. Gambar energi dan usaha } \\
\text { yang ditampilkan menarik }\end{array}$ & 3 & 3 & 3,00 & \\
\hline & 3. Bentuk huruf mudah dibaca & 4 & 3 & 3,50 & \\
\hline \multirow[t]{3}{*}{ Warna } & $\begin{array}{l}\text { 1. Warna yang digunakan } \\
\text { dalam media pembelajaran } \\
\text { menarik }\end{array}$ & 3 & 3 & 3,00 & 3,00 \\
\hline & 2. Gradasi warna sudah sesuai & 3 & 3 & 3,00 & \\
\hline & $\mathrm{V}_{\partial \text { media }}$ & & & & 3,00 \\
\hline
\end{tabular}


Keterangan:

$\mathrm{K}_{\mathrm{i}}=$ Rata-rata tiap kriteria

$\mathrm{A}_{\mathrm{i}}=$ Rata-rata tiap aspek

$\mathrm{V}_{\text {omedia }}=$ Rata-rata total validasi

Hasil analisis ahli media ini sudah menunjukkan bahwa media pembelajaran IPA Materi energi dan usaha ini valid karena nilainya di atas 3 yang bearti kriterianya valid.

\section{Analisis Kepraktisan media pembelajaran energi dan usaha}

Media pembelajaran interaktif energi dan usaha yang telah dikembangkan ini praktis. Hal ini disebabkan media ini memenuhi indikator yaitu validator menyatakan bahwa media pembelajaran ini dapat digunakan dengan sedikit atau tanpa revisi.

\section{Analisis keefektifan media pembelajaran energi dan usaha}

Media pembelajaran interaktif energi dan usaha yang telah dikembangkan ini dikatakan efektif karena memenuhi indikator adanya respon positif pengguna dalam hal ini Dosen dan guru yang ditunjukkan dari hasil analisis angket.

Tabel 5. Daftar Responden Pengguna

\begin{tabular}{clc}
\hline No. & \multicolumn{1}{c}{ Nama } & Profesi \\
\hline 1. & Yeri Utami, M.Pd. & Dosen STAI Muhammadiyah Blora \\
\hline 2. & Nuraini, M.Pd. & Dosen STAI Muhammadiyah Blora \\
\hline 3 & M. Nurul Ulum, M.Pd. & Dosen STAI Muhammadiyah Blora \\
\hline 4 & Dian Novika Dewi, S.Pd & Guru IPA Fisika SMK N Jepon Blora \\
\hline 5 & Teguh Eko P, S.Pd & Guru IPA SMP N 2 Jepon, Blora \\
\hline
\end{tabular}

Tabel 6. Analisis Data Angket Respon Pengguna

\begin{tabular}{|c|c|c|c|c|c|c|c|c|}
\hline \multirow[t]{3}{*}{ NO } & \multirow[t]{3}{*}{ Pertanyaan } & \multicolumn{4}{|c|}{$\begin{array}{c}\text { Frekuensi Pilihan } \\
\text { Jawaban }\end{array}$} & \multirow{2}{*}{$\begin{array}{l}\text { Nilai } \\
\text { Total }\end{array}$} & \multirow{2}{*}{$\begin{array}{l}\text { Rata- } \\
\text { Rata }\end{array}$} & \multirow[t]{3}{*}{$\%$} \\
\hline & & SB & $\mathbf{B}$ & $\mathbf{K}$ & TB & & & \\
\hline & & 4 & 3 & 2 & 1 & & & \\
\hline 1 & $\begin{array}{l}\text { Petunjuk } \\
\text { penggunaan } \\
\text { program jelas }\end{array}$ & 1 & 5 & & & 19 & 3,16 & 79,16 \\
\hline 2 & Keterbacaan teks & 1 & 5 & & & 19 & 3,16 & 79,16 \\
\hline 3 & $\begin{array}{l}\text { Kualiatas } \\
\text { tampilan gambar }\end{array}$ & & 6 & & & 18 & 3,00 & 75,00 \\
\hline 4 & Komposisi warna & 3 & 3 & & & 21 & 3,50 & \\
\hline 5 & $\begin{array}{l}\text { Daya dukung } \\
\text { musik }\end{array}$ & & 6 & & & 18 & 3,00 & 75,00 \\
\hline
\end{tabular}




\begin{tabular}{|c|c|c|c|c|c|c|}
\hline 6 & $\begin{array}{l}\text { Animasi yang } \\
\text { disajikan sudah } \\
\text { sesuai dengan } \\
\text { konsep materi } \\
\text { energi dan usaha }\end{array}$ & & 6 & 18 & 3,00 & $\overline{75,00}$ \\
\hline 7 & $\begin{array}{l}\text { Kejelasan tujuan } \\
\text { pembelajaran }\end{array}$ & 1 & 5 & 19 & 3,16 & 79,16 \\
\hline 8 & $\begin{array}{l}\text { Kemudahan } \\
\text { dalam memahami } \\
\text { kalimat pada teks } \\
\text { dalam media } \\
\text { pembelajaran }\end{array}$ & & 6 & 18 & 3,00 & 75,00 \\
\hline 9 & $\begin{array}{l}\text { Materi yang } \\
\text { disajikan dalam } \\
\text { media } \\
\text { pembelajaran } \\
\text { yang berbasis } \\
\text { multimedia dapat } \\
\text { dipahami dengan } \\
\text { baik }\end{array}$ & & 6 & 18 & 3,00 & 75,00 \\
\hline 10 & $\begin{array}{l}\text { Ketepatan urutan } \\
\text { penyajian }\end{array}$ & 2 & 4 & 20 & 3,33 & 83,33 \\
\hline 11 & $\begin{array}{l}\text { Kecukupan } \\
\text { latihan }\end{array}$ & & 6 & 18 & 3,00 & 75,00 \\
\hline 12 & $\begin{array}{l}\text { Kejelasan umpan } \\
\text { balik dan respon }\end{array}$ & & 6 & 18 & 3,00 & 75,00 \\
\hline 13 & $\begin{array}{l}\text { Interaktivitas } \\
\text { (adanya peran } \\
\text { aktif Mahasiswa) }\end{array}$ & & 6 & 18 & 3,00 & 75,00 \\
\hline \multicolumn{6}{|c|}{ Rata-Rata Total } & 77,56 \\
\hline
\end{tabular}

Media pembelajaran interaktif energi dan usaha layak digunakan karena mendapat respon positif dari pengguna yaitu guru IPA SMP.

\section{B. Pembahasan}

Berdasarkan hasil uji coba ahli dan pengguna yang telah dilakukan, maka media pembelajaran energi dan usaha ini dapat dimanfaatkan sebagai alat bantu pembelajaran IPA pokok bahasan energi dan usaha.Penggunaan program media pembelajaran relatif mudah dan sederhana.Program media pembelajaran ini baik dan layak digunakan karena telah memenuhi kriteria valid, praktis, dan efektif [4]. Dengan demikian program yang dibuat ini layak dijadikan sebagi media pembelajaran dan dapat dimanfaatkan dalam pembelajaran IPA pokok bahasan usaha dan energi untuk Program Studi PGMI STAI Muhammadiyah Blora. Hal ini dapat dilihat dari hasil uji coba 
oleh ahli materi dengan dua orang validator yaitu dosen Pembelajaran IPA Dosen STAI Muhammadiyah Blora dari aspek format sebesar 3,33, dari aspek isi sebesar 3,28, dan dari aspek bahasa sebesar 3,40. Hal ini menunjukkan bahwa media pembelajaran ini memenuhi kriteria valid karena karena nilainya diatas 3 .

Sedangkan hasil uji coba dari ahli media dengan dua orang validator yaitu dosen multimedia STAI Muhammadiyah Blora dari aspek kesederhanaan sebesar 3,12, dari aspek keterpaduan 3,50, dari aspek penekanan 2,50, dari aspek keseimbangan 2,75, dari aspek bentuk 3,16, dan dari aspek warna 3,00. Dengan nilai rata-rata 3,00 hal ini menunjukkan bahwa media pembelajaran ini memenuhi kriteria valid karena karena nilainya sama dengan 3 .

Analisis kepraktisan menunjukkan kalau media pembelajaran interaktif energi dan usaha ini praktis karena mempunyai nilai validasi 3 yang memenuhi indikator yaitu media ini dapat digunakan dengan sedikit atau tanpa revisi. Analisis keefektifan menunjukkan kalau media pembelajaran interaktif energi dan usaha yang telah dibuat ini efektif karena telah memenuhi indikator adanya respon positif dari pengguna dalam hal ini guru yang ditunjukkan dari hasil analisis angket sebesar 77,56\% yang berarti positif.

\section{KESIMPULAN DAN SARAN}

A. Kesimpulan

Berdasarkan hasil penelitian yang telah dilakukan dapat diambil kesimpulan sebagai berikut:

1. Pemanfaatan Multimedia Pembelajaran interaktif Pembelajaran IPA Pokok Bahasan energi dan usaha sebagai alat bantu Dosen dalam kegiatan pemkuliahan telah dihasilkan dan mendapat pengaruh positif dari pengguna yaitu Dosen dan Guru yang ikut serta dalam proses pemanfaatan tersebut.

2. Berdasarkan hasil uji coba dari para ahli media, materi dan pengguna, Pemanfaatan Multimedia pembelajaran interaktif Pada Mata Kuliah Pembelajaran IPA Pokok Bahasan energi dan usaha layak digunakan sebagai alat bantu Dosen dalam kegiatan Perkuliahan atau belajar mengajar.

\section{B. Saran}

Pemanfaatan Multimedia pembelajaran interaktif Pada Mata Kuliah Pembelajaran IPA Pokok Bahasan energi dan usaha di Program Studi PGMI STAI Muhammadiyah Blora ini mempunyai beberapa kekurangan yaitu :

1. Program yang dihasilkan hanya diiringi backsound musik, tidak adanya narasi suara sehingga diharapkan untuk pengembangan selanjutnya dapat menambahkan narasi suara agar penyampaian materi lebih jelas.

2. Program yang dihasilkan hanya menampilkan animasi dan simulasi dua dimensi sehingga diharapkan untuk pengembangan selanjutnya dapat dikembangkan lagi secara maksimal dengan simulasi tiga dimensi. 
3. Kurangnya contoh-contoh soal dan evaluasi dalam media pembelajaran interaktif pokok bahasan energi dan usaha sehingga diharapkan untuk pengembangan selanjutnya dapat diperbanyak untuk memperjelas pemahaman pengguna.

Aplikasi media pembelajaran interaktif energi dan usaha ini juga mempunyai beberapa kelebihan yaitu:

1. Adanya simulasi interaktif yang membuat mahasiswa bisa memberikan respon atau masukan sehingga terjadi komunikasi dua arah. Jadi Dosen disarankan menggunakan media pembelajaran ini untuk membuat mahasiswa lebih aktif dan memperjelas pemahaman mahasiswa tentang konsep energi dan usaha.

2. Gambar, animasi dan simulasi menarik yang disesuaikan karakteristik pemahaman yang mudah dipahami untuk mahasiswa. Disarankan dosen untuk memberikan pengantar atau cerita yang berhubungan dengan kehidupan sehari-hari sesuai ilustrasi dalam media pembelajaran sehingga pengguna lebih mudah memahami konsep energi dan usaha.

3. Adanya tools yang bisa membuat guru untuk bisa mengupdate soal-soal dalam evaluasi. Disarankan dosen atau pengguna untuk selalu mengupdate soal-soal dalam evalusi agar lebih memperkuat pemahaman mahasiswa ataupun siswa tentang energi dan usaha.

\section{DAFTAR PUSTAKA}

[1] Jumadi. 2004. Pengembangan Model Program Pengajaran Berbantuan Komputer untuk Remidiasi dalam Perkuliahan Fisika Dasar I. Prosiding Seminar Nasional Penelitian dan Penerapan MIPA UNY 2 Maret 2004: Yogyakarta.

[2] Wahyuni. 2007. Pegembangan Media Pembelajaran Dinamika Partikel Menggunakan Swishmax. Skripsi S-1, Universitas Ahmad Dahlan: Yogyakarta.

[3] Leong, Marlondan Mulyanta. 2009. Tutorial Membangun Multimedia Interaktif-Media Pembelajaran.Yogyakarta: Universitas Atma Jaya.

[4] Yamasari, Yuni. 2010. Pengembangan Media Pembelajaran MatematikaBerbasis ICT yang Berkualitas. Prossiding Seminar Nasional Pascasarjana X ITS. 4 Agustus 2010. Surabaya

[5] Arikunto, Suharsimi. 2007. Dasar-dasar Evaluasi Pendidikan (Edisi Revisi). Jakarta: Bumi Aksara. 